\title{
Intercultural Dialogue among the Elderly in Zadar Area, Croatia
}

\author{
Olga Orlić
}

\begin{abstract}
The objective of this paper is to reveal the complexities of the contemporary perceptions and attitudes of the elderly from Zadar and its surroundings about the cultural heritage of the town they live in, including its multicultural history and opportunities for intercultural dialogue offered by the city's legacy. This paper presents results of the analysis of data obtained by qualitative methodology i.e. by semi-structured interviews carried out with members of the home for the elderly in Zadar during 2016. The analysis and results point to the fact that interviewees in Zadar, due to city's historical context and their own life trajectories have a quite negative approach toward intercultural dialogue, that is not quite in line with the contemporary global discursive promotion of intercultural dialogue as the tool that could help facilitate conflicts raised by multicultural reality.
\end{abstract}

Index Terms-Intercultural dialogue, multiculturality, tolerance, Zadar, Croatia.

\section{INTRODUCTION}

Zadar, a city on the Eastern coast of Adriatic has often been perceived in public discourse as "the most Croatian city of them all". These words are ascribed to first president of Croatia, Dr. Tuđman in 1993, upon receiving the award of honorary citizen of Zadar [1]. Zadar has been under siege during the Homeland War (Croatian War of Independence (1991-1995) that followed the break-up of Yugoslavia) and the city and its inhabitants have suffered a lot, therefore it is no wonder that there was and still is a strong feeling of national pride regarding the war events and the role of Zadar in it. After all, even during the years in which it was not politically wise to support general Ante Gotovina, the Zadar city walls were decorated with huge poster with his photo

Manuscript received June 10, 2017; revised August 12, 2017. This work was supported by the Croatian Science Foundation under Grant 3914 (Historical Perspectives on Transnationalism and Intercultural Dialogue in the Austro-Hungarian Empire) carried out at the Institute for Anthropological Research in Zagreb (P.I. Anita Sujoldžić). This paper is a result of the qualitative research carried out within the frame of this project. The aim of the project is to counterbalance the historiographic approach to the Austro-Hungarian Empire in Croatia based on exclusive national canons and the national identity. It focuses on the cultural and linguistic heterogeneity and transnational practices in the period of Austria-Hungary in 4 Croatian cities (Zagreb, Zadar, Rijeka and Pula), and potential intercultural practices that existed at that time. Although a major part of the research is based on archival data, the contemporary attitudes toward Austro-Hungarian legacy and cultural heritage have been analyzed as well. It included not only tangible and visible legacy, but intangible aspects as well. Our specific goal was to detect a possible contemporary memories (and maybe even nostalgia) of intercultural dialogue as a feature that existed (if so!) in the period of multicultural and multiethnic Monarchy.

Olga Orlić is with the Institute for Anthropological Research, Ljudevita Gaja 32, 10000 Zagreb, Croatia (email: olga.orlic@inantro.hr). under which it was written "Hero, not a Criminal". Other prominent individuals also stated that "Zadar is the most Croatian city, despite being built by the Romans" [2]-[3]. Zadar was rebuild and repopulated after the World War II when the city suffered a huge demolition (the city was bombed by the allies (because it became, after the fall of Austria-Hungary, the part of the Kingdom of Italy). During second Austrian rule in Dalmatia (including Austro-Hungarian times, when it belonged to the Austrian part of the Dual Monarchy, so called Cisleithania) Zadar was the administrative center of the crown land Kingdom of Dalmatia. This was one of the reasons why it inevitably attracted people from different parts of the Monarchy, adding to the cosmopolitan spirit of the city. In 1869 Zadar had 1 urban and 21 rural settlements, with over 20.849 inhabitants, and in 1910 it had 37.580 (without soldiers). In this period the ratio of Slavic and Italian language users (the census carried out by the Austrian government did ascribe the language use with nationality, therefore it cannot be taken as a reliable source for ethnicity, since the linguistic situation was more complex than the ethnic one) changed (from $2 / 3$ in favor of Italian, into 50:50 ratio) [4]. As the capital of the province, Zadar was, naturally, the city of administration as well as of craftsmen coming from all parts of the Monarchy. Peričić mentions several fishermen in Zadar originating from Italy, providing their family names, but there is a lot of archival documents about numerous prominent Zadar families coming from the territory of nowadays Italy earlier in history. There were some more entrepreneurial efforts that caused workers migration to Zadar. Zadar was famous for its Maraschino cherry liquor and there were many manufactures in the city. Having in mind that Zadar was a place of contact between various cultures throughout history (its position near the Triplex Confinium, the historical border between Austrian, Ottoman and Venetian Empire had and still has important impact on the multicultural reality of the area), and that as a center it was a place of constant immigration (including Arbanasi from Albania, various Italian families that co-shaped the political and economic life in the city [5].

After the WWII the power relations changed and the demographic picture of Zadar as well (this especially refers to Italians, who before WWII in Zadar were not just a strong political factor but one of the most prominent inhabitants in the city. Having in mind such a complex demographic situation, tremendously rich cultural heritage from various historical period, and the fact that $80 \%$ of Zadar was destroyed during the WW II, together with contemporary discursive construction of Zadar as the most Croatian town it is interesting to examine the attitudes of contemporary, especially elderly people toward Zadar multicultural legacy 
(not referring exclusively to its tangible aspects, such as architecture and monuments, but toward more intangible aspects of everyday life, such as intercultural dialogue).

\section{INTERCULTURAL DiALOGUE AND ITS DisCONTENTS}

The growing debate about intercultural dialogue (from now on, I will use the abbreviation ICD), interculturalism, and accompanying tolerance is becoming important aspect of public discourse in the situation when multiculturality becomes more and more visible, especially in the Western World. Multiculturality is not a new, unprecedented global condition, but rather one of realities people live continuously in, (including various mutual relationships) in both past and present. Politics of multiculturalism (referring also to the ways to handle and harmonize this cultural diversity in terms of citizenship and civil rights) are becoming not only the important political and public topics, but the topic of scholarly debate as well [6]-[7]. In the contemporary European society the issue of internal mobilities of European peoples has been complemented by the problematizing of the new influx of people from other parts of the world, mainly refugees. Therefore it is no wonder that numerous international organizations and institutions such as UNESCO and Council of Europe devoted a lot of time and discursive effort into building in an intercultural dialogue as one of the core values of the world in general and the European society in particular.

The concept was extremely viable in the past decades, and has been incorporated into the official and unofficial documents and educational programs of international organizations such as UNESCO, the Council of Europe (CoE), and the European Commission (EC). The importance of ICD has been justified by the "turbulent international globalized landscape," [8] or by cultural diversification due to "migrants in search of a better life and asylum-seekers" [9], although the incensement of travel and tourism enabling the face to face interaction was not neglected. In this context the need for pluralism, tolerance and broadmindedness is considered to be of extreme importance, although ICD itself is not sufficient. CoE has collected the examples of good practice across the countries. The European Court of Human Rights recognized that pluralism is built on "the genuine recognition of, and respect for, diversity and the dynamics of cultural traditions, ethnic and cultural identities, religious beliefs, artistic, literary and socio-economic ideas and concepts". In order to make the pluralism a building block of the European society "a pro-active, a structured and widely shared effort in managing cultural diversity is needed. Intercultural dialogue is a major tool to achieve this aim, without which it would be difficult to safeguard the freedom and well-being of everyone living on our continent." [9]. The ICD is further being promoted as a desirable European value, including e.g. efforts such as European Commission's decision to dedicate the year 2008 to be the Year of Intercultural dialogue, followed by accompanying promotional activities, including financing projects such as Sharing diversity: National Approaches to Intercultural Dialogue in Europe [10]. These activities of EC regarding ICD (especially having migrants and refugees in mind) continue and the importance of ICD is stressed in numerous projects that EC finances, such as Creative Europe, various collaborative projects, and cinema as well.

However, ICD is not a concept invented by politicians to promote values that should be cherished among peoples in order to avoid conflict and war. As pointed by Aviva Doron, ICD was considered "similar to the dialogue between persons" [11:265]. She introduces the concept of intercultural person, as someone who "possesses an intellectual and emotional commitment to the fundamental unity of all human beings and, at the same time, accepts and appreciates the differences that lie between people of different cultures". Usually anthropologists like to perceive themselves as the ones who apply such cultural relativism (also mentioned in [9]) in their gaze and could be described as individuals who try to understand the culture within its own value system. And one should actually have in mind the role of anthropology Marcus and Fisher stress, to enhance cultural critique, but of one's own culture [12]. However, world is not full of anthropologists equipped with "desirable" ICD skills (if we consider anthropologist to be more prone to ICD) and therefore it is necessary to apply the critique of the ICD scholarship in order to be able to grasp its limitations. Lee pointed out how the growing field of research about ICD and the whole concept of its promotion points to three main problems that researchers should be aware of: (a) talk in ICD as a mean of expression and solution, (b) ICD as an elitist representation, and (c) ICD scholarship as a place for Western domination [13]. First, if the ICD is conceptualized as a talk that can help participants to build a trust, to reach mutual agreement and to reduce ethnocentrism and xenophobia, it is clearly perceived as a tool for fixing problems arising from intercultural differences. Having that in mind, one can analyze, for example, public discourse (of UNESCO, the Council of Europe and similar organizations) of ICD as the totally utilitarian and goal-oriented one [13: 237]. Lee stresses that this utilitarian, goal-oriented approach, when applied to ICD, may also result in efforts to relate and to build relationships being overshadowed by the need to solve problems. Regarding problem stressed under b) Lee concludes that ICD research, even carried out in the non-Western settings, are often "conducted by and on participants who are privileged and non typical" [13: 239]. Also, scholars of ICD are predominantly using westernized methods and scholarship. Lee states that, in general, academics rarely have the time or resources to immerse themselves in and learn the communication codes of other cultures (although this should not apply to anthropological work that usually strives to grasp these codes throughout detailed ethnographies) in order to engage effectively in ICD. This could be improved, Lee suggests, by expanding the scope of research to include poor and underprivileged people (not exclusively on only so-called muted groups of non-Western elites) and giving voice to truly muted communities. Similarly as in the previous point, in c) Lee argues that ICD scholarship in and of itself can be viewed as a place for power struggle. She stresses the fact that domination of Western ideologies and the preservation of Western scholarship practices is a reassertion of the Western power in defining the human experience and generating new knowledge. This also includes the knowledge about ICD. As 
a negative approach Lee mentions how quite often in the ICD research the anthropological gaze is applied and that it refers mostly to the exotization of the Other. Anthropologist themselves are quite aware of that problem and do try to avoid such a practice. Lee therefore argues for the deconstruction of the Eurocentric, Western academic nature of ICD scholarship [13:240].

Having in mind that in the public discourse ICD is primarily perceived as a political and ideological concept (or a tool) and that it might not reflect the "situation on the ground", especially not among "ordinary people", I will try to analyze data obtained from semi-structured interviews carried out in 2016 in the home for the elderly people in Zadar (Zadar). Regarding the interlocutors, it is interesting to note that a majority of them do not originate from Zadar (this was not a requirement for their inclusion in the "sample" we just wanted our interlocutors to express their opinions and knowledge (or lack of it, as equally resourceful information) toward the multicultural legacy of the city of Zadar). This also reflected the context of Zadar history as well, especially the fact that after the WWII, when "the city was empty", newcomers to the city arrived. The majority of them barely finished elementary school (they belong to the interwar generation when either war stopped the education, or the education was not perceived to be so important (especially regarding girls); only few of our interlocutors obtained a university degree.

We wanted to see what they think of ICD and if ICD was recognized as a part of cultural identity of the city at all. Zadar, after the World War II changed not only its rulers but also its landscape (after the capitulation of Italy, until 1 November 1944 Zadar was under the local Italian governance accompanied by the German protection. Zadar was bombed since November 1945 till October 1944, including the very last day of occupation (31 October 1944), when partisans (i.e. National Liberation Army) entered/liberated the city. During these attacks, majority of the city was destroyed and most of the city's population fled away. Italian population was prior to WWII one of the most prominent in the city. For example Tea Sindbæk Andersen writes about the Luxardo family, the owners of the Maraschino manufacture, their importance for the legacy of the city and how they also left the city. She also writes about the way how today legacy of their factory (and the famous cherry liquor Maraschino) has been branded and how the efforts are being made in order to promote this past legacy as something distinctive of Zadar. Also, she tackles complex issues of the memory of Zara (Italian name for Zadar) being maintained among some members of the Zaratini community (Italians from Zadar that left after WWII) [14]. Going back to Austrian times, although quite significant for the history of the city, it seems that it didn't take a significant role in the accounts of our interlocutors. Here in Zadar, the construction of Habsburg nostalgia, that is quite often being built in the countries successors of the Austro-Hungarian Monarchy [15], regardless of the fact how the Habsburg nostalgia is perceived (as e.g. in [16]), hasn't been actively employed. The myth about Austria, prominent in some other parts of Croatia (see for example [17]) yet does not exists in Zadar and the easiness with which this nostalgia is, according to some scholars, switched by pan-European ideas [18] hasn't been recognized yet. Only few of our interlocutors knew about buildings in the city from that period and majority was not aware of the fact that it was the time when also a lot of newcomers arrived in the city, due to industry, administration or some other reason [4]. Very few interlocutors mentioned some members of the family that were employees of the state during the Austro-Hungarian times, (one rare example of family experience is the example of one interlocutor's aunt who married a Hungarian man).

So, like in many parts of Croatia, the period after the WWII was the period when the population changed significantly. It is interesting that some of our interlocutors, when asked about the interview and when being explained the goal of our research, used the term "empty" while describing the situation of Zadar after the World War II. This emptiness refers to the one of the cities targeted by the project, together with Pula, Rijeka and actual appearance of the city, but too the gap in the history, I would add, as well. And it came out, later in interviews, to be an important marker, since more than half of the interlocutors actually came to Zadar after WWII. However, for the majority of interlocutors Zadar was the arrival city, the place where they struggled to prosper (see Arrival city, Sounders 2010 in [19]. And some of the interlocutors are actually from islands nearby Zadar, and they came to the home for the elderly in Zadar simply because there is no such home on their island. And after the Austro-Hungarian demise, Zadar was given to the Kingdom of Italy, but not the islands near Zadar - they belonged to the Kingdom of Yugoslavia, and this actually meant that these islanders did not share the history of Zadar until the end of WWII although. However these people also recall the bombing of the city.

One interlocutor from the neighboring island of Pašman remembers how the bombing of the Zadar looked like from his house in Banj:

„From the house in Banj, when they throw missiles on it [the city]...(...)....you have 8 miles, multiply with 1852 meters [explaining the distance between Pašman and Zadar] you could easily, like it is said, put the thread into eye of the fine needle, with us, that much light it was".

As already mentioned, a lot of interlocutors did mention, usually before the interview, when explaining the fact that they moved to the city after WWII, that Zadar was empty after the war. Although they did not stress it directly, this fact (emptiness of the city, they as newcomers) could explain their poor knowledge about the Zadar history prior to their arrival. This lack of knowledge was quite apparent during the interviews. The history and the cultural heritage, especially the one connected with the Austro-Hungarian period in the city was quite irrelevant or simply unknown for the majority (not all of them though!) of our interlocutors.

The post WWII i.e. second Yugoslav period was, logically, most familiar for most of them even make connection between what they labeled as Yugoslav mentality, with some of the negative events that happened immediately after the WWII, while the city was still empty: 
I saw when I arrived here in '45, it was bombarded, Zadar, and what were they after? Just how to steal what was inside, they even took the wires off, counters, sockets, all together, in those ruined buildings. We were real "Jugovici $i$ " back then.

This honest admitting of war theft that happened at the time, was characterized negatively by the interlocutor who himself was a member of partisan National Liberation Army, originating from the nearby island of Olib. It is interesting that he denotes the negative characteristic to the mentality of Jugović $i$ (he himself proudly states that he always claimed his Croatian national identity, even during the Yugoslavian period and if taking this statement into account, it is not wonder that bad behavior was described as the Yugoslav way of doing things (it is also interesting that in this way he shared the responsibility among all the ethnic groups that were constituents of Yugoslavia, and simultaneously skipped to pinpoint at one or two).

\section{Multiculturality In ZADAR AREA}

\section{A) "...there were Croatians and Serbians, there were Arbanasi, than Italians...”}

So when asked about multicultural reality and intercultural dialogue our interlocutors mostly mention the period that was most familiar to them, the period after the WWII when people from all over the Yugoslavia filled in the empty city, that was under the Italian rule before.

It was the time when the most of "it" [meaning them, people arriving in the city] settled here.

However, they became aware of the fact that various ethnic groups live there:

Well, I didn't know until I arrived - Zadar was Italian, how many people were there, they say that there were Croatians and Serbians, there were Arbanasi, than Italians...

When multiculturality was mentioned, quite a few of our interlocutors mentioned Arbanasi, as "an example of multiculturality". Arbanasi, once a village next to Zadar and nowadays a part of the city was inhabited during the first half of 18 century by the Roman-Catholic Albanians from the area near the Skadar lake [20]. They managed to preserve their language until recent times, and today only elderly people use the language [21]. The reasons for mentioning Arbanasi are quite clear, because they represent rather old (and rather compact and small) minority group that managed to assimilate into the society. I do not mention assimilation exclusively in the sense of social identity being incorporated or digested, as one of the meanings elaborated by Brian Barry, but also refer to the other, also mentioned meaning, that is more connected with the etymology of the word - to make or be alike [7:72]. Having in mind Barry's point that assimilation is a "response to a situation in which the possession of a distinct identity is strongly disadvantageous"
[7], it is interesting that one of the interlocutors from Arbanasi did not mention his Arbanas identity at the beginning of our conversation (this popped up only later during conversation). It was not clear to me was he feared that he would be stigmatized for his Arbanas identity, or not. Instead he mentioned his double Italian-Croatian citizenship and his working experience abroad. Only later in the conversation did he mention that he actually speaks arbanaški (even corrected the way I pronounce the word) and shared the anecdote about him and his friend speaking arbanaški and a visitor who does not understand the language they speak.

And then we would go to Interspar to take a coffee. We were drinking coffee and one man was writing something and all the time he was looking at the two of us. He stood up, [and asked them]: Please would you tell me which language are you speaking? (laughter. )And X (the name of the friend) quickly responded: Esperanto!

Finally he admitted his Arbanas identity and even tried to rationalize why arbanaški is not in use among younger generations so much. He even explained the reasons why his kids do not speak it (his wife does not speak arbanaški and therefore they did not communicate to each other in arbanaški and their son was not able to learn the language).

You don't have that any more - my son complaints to me all the time why I haven't thought him arbanaški. My son, as first, your mother is Turanjka (from Turanj), she did not know arbanaški, and the language is learned by listening...(...) much more by listening then by reading.

Apart from Arbanasi, multiculturality and the issues connected with intercultural dialogue and tolerance were far more elaborated in relation to another minority group, who are also not newcomers to the region - Serbians.

\section{a) "In that times we were doing $O K$ "}

Majority of our interlocutors, even those that did have Serbian origin or someone in the family of Serbian origin, quite openly described mostly negative (contemporary) attitudes toward Serbs. However, it has to be said that they did proudly mention having Serbian friends and that they mentioned Serbian members of the family without a second thought.

Since the Homeland War, they became the most significant Others in the region and the conversations about tolerance and intercultural dialogue (especially between Croats and Serbs) actually reveals all the complexity and nuances that are usually not acknowledged in desire to either solve or enhance the conflict (because not only ICD as a tool approach is at work), adding to the critiques of ICD scholarship Lee has taken. It revealed the situation where people, usually having no higher education, express their attitudes without being afraid of being understood as politically incorrect. The majority did mention the fact that the way of behaving between Serbs and Croats drastically changed after the Homeland War. They mentioned that they used to go along well until that war.

„In Benkovac,... these few years while I was [there] I 
gained friends of this other... And even our village was half-national, one half Serbs, half... We used to say Orthodox and Catholics...half of the village were we...Great, in that times we were doing OK. And even during the WW II, trust me. Not a single house did get hurt, not a single man, either theirs or ours, the village was peaceful... What was in the war, ok, but not even a single house was burnt down, in those days the Italians were the ones who burned down the houses...

This paragraph shows that it was religion, and not ethnicity, that was the main marker of identity. However, the interethnic marriages represented also a way of practicing intercultural dialogue. One interlocutor, who strongly emphasized her own Croatian identity, even used the term "half-believer" (poluvjerac) for her own mother when she, after being widowed, re-married an orthodox. However she remembers how the mutual relationships between families were quite good:

And you know, the people were, it was not like today, before, you used to love and respect each other.

When speaking about the Yugoslavian period, when a lot of people came to Zadar, interlocutors remember that ethnicity did not play such a role in their everyday life:

\section{Nobody paid attention to it.}

This was particularly true for the men, who did have experience from the obligatory military service and they did mention that there were much more understanding among peoples:

It was better...more hanging out together regardless of nation [national belonging]. And now? Well, now there is less of hanging out together, those that were here they fled... [I ask if he refers to Italians or Serbians]... I meant Serbians...I do not hate anybody. I love everybody; this is how I was raised. In the army [JNA- Jugoslavenska Narodna Armija - Yougoslav People's Army] we were thought to respect everybody, if he is a good man, that there is no need to hate anyone. Eh, and what happened then? You know, the managers [the term interlocutors used for the political leaders] are guilty, always like that. The managers who are up there are guiltier than we below. People always manage to find their way together. Here, if you listen, in our parts of the land, we always were good together, we never argued, we managed to communicate, but somebody else seduced us..."

However, as the other interlocutor mentions, the experience of war changed that tolerance quite a lot:

Before, when we were still in ex-Juga, I wasn't taking care about nationalities, I was good with everyone, but then I saw... (...)... I happened to be on the first line [during the war] by chance...

The impact of war on relationships among people is something that interlocutors did mention a lot. However, one lady did mention, apart from was, the postwar transition to capitalism as a mechanism that also diminishes mutual solidarity.

I think that people have distanced themselves from each other because of different events people lived through....everything... there were tragedies, and this continues....It is normal [in the sense: to be expected] to an extent...And then this capitalism came, although it is kind of a mixture, so in the firms where people work the relationships between individuals are not as they used to be...

During the war a lot of Serbians fled the area.

After this war...people didn't know where to go and what to do...(...)..some of them thought - the one who stays is doomed. Because you never know what the war brings... And some of them were taken by their own, and they left...

Somehow they un-mixed, they run away, now they are returning... Why are you returning if you have left? Isn't that true? If I left, I would have never ever returned.

These two excerpts from the interviews show the rationalization behind the decisions of Serbian families that decided to flee before the Croatian army regained the territory under their control. Despite the fact that it seems like a rational decision in uncertain war times (and that even one interlocutor explained this by the following sentence: "because you never know what the war brings"), in the second sentence the very same-interlocutor reveals the opinion about Serbian families being tricked (in terms that they were scared that somebody will do them harm) to leave. By this statement interlocutor expresses his opinion that it this case the war would not bring any harm to these Serbian families and this ambiguity shows how complex and difficult it is not only to make decisions during wartime, but to rationalize these decisions afterwards.

The second excerpt shows quite clearly the attitude of the interlocutor how the fact that Serbian families that left have shown whose allies they were and that therefore they should not return. The issues of transferring guilt from individuals to groups and vice versa are extremely complex and this issue is beyond the scope of this paper. The negative attitude toward mixed situation was expressed by one other interlocutor

I think the more people are, we say, mixed, it is worse...This is how we, the older ones, think, and now, how the youngsters think....

One interlocutor even replied to my question about the way to describe her identity: "Hell yeah, I am not a Serbian".

The attitude that you should be polite toward people of other (in this case quite stigmatized) ethnic identity, or at least check that s/he was not offended I felt on my own skin when one interlocutor said something unfavorable about Serbians and then looked at me and said that he hopes that he did not offend me, because I might be "theirs". However, he did not show intention to question his own statements or ideas, or to change his mind, he just wanted to make it clear 
for me that this is his opinion, regardless of what I or others might think about it, but he also wanted to show that he is able to judge people individually.

Despite the fact that majority of the interlocutors have shown that to build ICD on the war affected territory is extremely difficult, they expressed the opinion that each person should be approached individually and that it is not important who s/he is (in terms of ethnicity) but how s/he behaves.

\section{b) “What are those people like?"}

Being intrigued by the fact that ICD is not among the most appreciated values among interlocutors in home for the elderly in Zadar, we also asked them about the attitudes toward the refugees. They expressed genuine worry and concern:

I know, this great violence that is coming, it makes one to think whether it will be some change and similar...Too many people, OK, there is war down there and so on, and people run towards where is good for them, but it is difficult to guess if this will be worse...I heard that we will also accept refugees [referring to the fact that Croatia agreed to accept a certain number of refugees, according to the EU agreement], and now, this is the question... What we, among ourselves, are discussing is: What are those people like? Are they hard working, do they like to work or not, and when they arrive here, how they will adapt to our area...This is a little bit more difficult...

The Serbs alone, how many troubles did they give us? And now I am afraid that these, these refugees, that someone will encroach here, somebody will give him the house...(...)...anything can arrive...because, we are peaceful people and altogether, but if we will have some kind of ceremonies, I would not like that...

In general, people consider that it is the newcomers that should adapt to the domestic people, not vice versa. It is similar in the areas of Croatia that have built the whole regional brand based on multiculturality i.e. pluriethnicity and intercultural dialogue as a feature that distinguishes the region from the other regions [22]. So, this discourse is typical even for the more politically correct areas within Croatia. It is interesting that the metaphor of hospitality is used by some interlocutors in order to explain:

I would like you to accept what is mine, because, it is you who have arrived at my place, I didn't come to you place. (speaking to me, as if I was her guest):

\section{Or, more general:}

It is to respect what is in the country you are in... This is how we must respect - Where I arrived, it is I who have to pay respect.

\section{CONCLUSION}

The history of Zadar reveals that it is, like many parts of the world, multicultural. The newcomers were arriving over centuries into the city, either individually, or as part of organized efforts (where the whole groups were moved) in order to fill up the empty lands during the era of Ottoman threat. The Austrian rule in Dalmatia brought numerous administrators not only from the nearby places, but from other parts of the Monarchy. The World War II, the new geopolitical situation accompanied by the change of political system brought into the city significant demographic and population changes as well. The majority of the people living in Zadar (including Italian elites) left after WW II leaving the city quite empty. Due to heavy bombing the city had to be rebuilt as well. Zadar as the arrival city welcomed newcomers from the surroundings and from different parts of newly founded FNR Yugoslavia. However, although the knowledge about multicultural history of Zadar does exists among scholars and some individuals, the attitudes of majority of our interlocutors toward multiculturalism was colored negatively, since they connect it with the relationship with the latest war events. The Serbian minority is not a new minority in Zadar and surroundings, and the narratives about the past peaceful co-existence show that these two groups were able to practice tolerance and quite harmonious mutual relationships. The war events show how easy it is to dismantle fragile harmonious relationships and everything that was built by it and how difficult it is to rebuild it after being destroyed or diminished. And the efforts to create harmonious or more harmonious relationships (achieving harmonious ICD) have to be made having in mind that it will take much more time than policy makers assume, as this excerpt might show:

I have no interest in that, I have certain age, I have been through everything, war, war hospitals, I saw everything, the man killed, it was everything, and you had to do that because you worked there, you have to take it and forget it, to be able not to think about it anymore... It is difficult... Because you saw, you have tried, our people is always better, I can honestly say, you have passed through everything, you have seen everything...

\section{Future RESEARCH AND ANALySES}

Since this paper represents only a small portion of the qualitative research carried out in the cities of Pula, Rijeka and Zagreb as well (these four cities have been chosen for the research since they all were important places during the Austro-Hungarian times (Zagreb was the capital of Croatia and Slavonia, that was separate administrative unit within Hungarian part of Monarchy, Rijeka, important port city, was corpus separatum, belonging also to Hungarian part of Monarchy, Pula was chosen in the middle of the 19th century to become the Central Military port of Austro-Hungarian Monarchy and this fact fostered the development and growing of the city and Zadar was, as mentioned a capital of Kingdom of Dalmatia, the last two cities mentioned belonged to the Austrian Part of Monarchy. The interviews among the elderly population in all these cities have been carried out, and the further comparison will be made in order to put these data from Zadar in a wider context. However, even from the preliminary analysis it is possible to conclude that for 
example, the attitudes of elderly from Zadar are quite different when compared to the attitudes about intercultural dialogue, tolerance and multiculturality among the elderly in Pula in Rijeka. These two cities have been branding themselves as multicultural and diversity friendly (Rijeka has won the title of European Capital of Culture 2020 under the slogan "Rijeka - Port of Diversity), and the whole Istria region (Pula is the largest city in that region, the only official bilingual region in Croatia (Croatian-Italian) has been branding itself as multicultural region [22]. Therefore the attitudes of elderly from Zadar are quite opposite to those of elderly in Rijeka and Pula. In order to clarify in more depth these differences, further analysis has to be made. The analyzed data from Zadar point to the fact that a lot of antagonisms and disagreements come to the fore while discussing issues such as tolerance, diversity, minorities, refugees, even intercultural dialogue. Intercultural dialogue is not necessarily pointing to the harmonious relationships among people belonging to diverse ethnic or otherwise divided groups. These relations are sometimes harmonious and sometimes not, depending on the contextual situation(s). And since the rising perceptions of ICD as a tool that could help achieving mutual understanding among cultures, this paper points to the facts that "ICD as a tool" approach has its limitations and difficulties. Honest, maybe sometimes not so politically correct attitudes of elderly people from Zadar point to the much longer timeframe needed to rebuild better mutual relationships after conflicts than dominant approach to ICD as "ready to use tool".

\section{REFERENCES}

[1] Predsjednik Republike Hrvatske dr. Franjo Tuđman u Zadarskoj županiji: Dr. F. Tuđman: "Zadar - najhrvatskiji grad”. Slobodna Dalmacija. [Online]. Available: http://arhiv/slobodnadalmacija.hr/11121999/zadar.htm

[2] B. Kupčak. (November 28th' 2010). Preminuo književnik i "proljećar" Julije Derossi, Zadarski list. [Online]. Available: http://www.zadarskilist.hr/clanci/28112010/preminuo-knjizevnik-i-pr oljecaj-julije-derossi

[3] M. Kovačević, "Julije derossi (Trogir, 9. Srpnja 1928-Zadar, 28. Studeni 2010)," Croatica et Slavica Iadertina, vol. 7/2, no. 7, pp. 475-477, 2011

[4] Š. Peričić, "Povijest Zadra u XIX Stoljeću”, in Zadar za Austrijske Uprave, Peričić, Šime, Ed. Zadar: Matica Hrvatska, 2011, pp. 13-257.

[5] D. Kolić, "Inventar fonda obitelji Lantana," Radovi Zavoda za Povijesne Znanosti HAZU u Zadru, vol. 49, pp. 355-437, 2007

[6] W. Kymlicka, Multicultural Citizenship: A Liberal Theory of Minority Rights, Oxford: Clarendon Press, 1995.

[7] B. Barry, Culture and Equality: An Egalitarian Critique of Multiculturalism, Harvard University Press, 2001.

[8] Intercultural dialogue. UNESCO. Available: http//en.unesco.org/intercultural-dialogues

[9] White Paper on Intercultural Dialogue: "Living Together As Equals in Dignity," Council of Europe, June 2008.

[10] Sharing Diversity: National Approaches to Intercultural Dialogue in Europe, Report for the EC, 2008

[11] A. Doron, "Towards a Definition of Intercultural dialogue," Encyclopedia of Life Support Systems (EOLSS):, Place, Literature and Arts, pp. 262-283.

[12] G. E. Marcus and M. M. J. Fisher, Anthropology as Cultural Critique: An Experimental Moment in the Human Sciences, Chicago: University of Chicago Press, 1986.
[13] E. .L. Lee, "Intercultural dialogue in theory and practice: A review", Journal of Multicultural Discourses, vol. 11, no. 2, pp. 236-242, 2016.

[14] T. S. Andersen, "Zaratini. Memories and Absence of the Italian Community of Zadar" in Whose Memory? Which Future: Remembering Ethnic Cleansing and Lost cultural Diversity in Eastern, Cenral and Sotuheastern Europe, Barbara Törnquist-Pleva, ed. New York, Oxford: Berghan Books, 2016, pp. 143-169.

[15] A. Kożuchowski, The Afterlife of Austria-Hungary: The Image of the Habsburg Monarchy in Interwar Europe. Russian and East European Studies Series. Pittsburgh: University of Pittsburgh Press, 2013.

[16] S. Winker. (May 2014). The house of Habsburg, Revisited. Foreign Policy. [Online]. Available: http://foreignpolicy.com/2014/05/27/the-house-of-habsburg-revisited/

[17] L. Nikočević, Lidija, and N. Škrbić. "Način gledanja: Mit o Austriji u Istri," in Istra: Različiti Pogledi, L. Nikočević, Ed. Pazin: Etnografski muzej Istre, 2002, pp. 37-52.

[18] J. Hagen, Redrawing the imagined map of Europe: The rise and fall of the “center", Political Geography, vol. 22, pp. 489-517, 2003.

[19] G. van Hengel. Arrival in the city - The radicalization of Gavrilo Princip. [Online]. Available: http://konferencija2014.com.ba/wp-content/uploads/Guido-van-Heng el-paper.pdf

[20] M. Diklić, "Pojava i razvoj pravaštva u Arbanasima kod Zadra," Rad. Zavoda Povij. Znan. HAZU Zadru, vol. 48, pp. 655-665, 2006.

[21] M. Barančić, “Arbanasi i etnojezični identitet," Croat. Slav. Iadert, vol. 4, pp. 551-568, 2008.

[22] O. Orlić, "Mnogoznačje istarskog multikulturalizma," Etnološka Tribina: Godišnjak Hrvatskog Etnološkog Društva, vol. 38, no. 31, pp. 39-59, 2008.

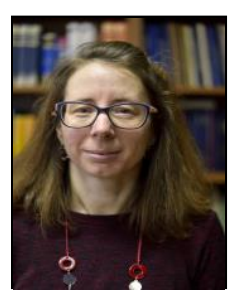

Olga Orlić was born in Zagreb in 1976. She graduated ethnology and archeology in 2000, gained M.A. in ethnology and cultural anthropology in 2008 and $\mathrm{Ph} . \mathrm{D}$. in anthropology. She obrtained all degrees at the Faculty of Humanities and Social Sciences University of Zagreb (Croatia).

From 2000- 2006 she worked as a curator at the Ethnographic museum of Istria in Pazin. From 2006 she works as research assistant at the Institute for Anthropological research in Zagreb. In 2013 she was elected scientific asssociate/research fellow at the Institute for Anthropological Research in Zagreb. She collaborated on numerous national and international research projects (FP6, Ministry of Science, Education and Sports, Croatian Science Foundation, Bilateral projects with Austria and Macedonia and more) and has published papers in international and national journals. In 2014/2015 she was in charge for the program of popularization of science (anthropology) AntroPOP, financed by the Ministry of Science, Education and Sports of the Republic of Croatia. In the period 2007-2016 she was teaching assistant at the study of anthropology at the Faculty of Humanities and Social Sciences University of Zagreb. Her research interests include but are not limited to the following topics within the frame of socio-cultural and linguistic anthropology: identity and identification processes, linguistic diversity, cultural diversity, stereotypes / stereotypization, tourism, cultural tourism, solidary economy, community-supported agriculture, rural development.

Dr. Orlić is an active member of Croatian Anthropological Society (HAD), Croatian Ethnological Society (HED, International Union of Anthropological and Ethnological Sciences (IUAES), European Association of Social Anthropologists (EASA), International Society for Ethnology and Folklore (SIEF) and Society for Applied Anthropology (SfAA).

In the period $2008-2012 \mathrm{dr}$. Orlic was the organizer of the Club of the Croatian Ethnological Society. In the period $2005-2008$ she was a member of the Governing Board of the Croatian Ethnological Society. Since $2008 \mathrm{dr}$ Orlić is a member of the Editorial Board of Etnološka tribina / Ethnological Forum Journal, the Journal of the Croatian Ethnological Society. She worked in scientific committees for organizing Island Dynamic Conference and IUAES conference held 2016 in Dubrovnik. In 2005 she was awarded "Milovan Gavazzi" Annual Award of the Croatian Ethnological Society for the best ethnographic exhibition ("Weavers in Istria") held in 2004. 